\title{
LOS FUTURISTAS Y EL CINE
}

\section{Aurelio de los Reyes}

¿Cuándo, cómo, dónde y por qué los pintores futuristas entran en contacto con el cine? Difícil precisarlo porque los estudios sobre ellos no han tomado en cuenta cabalmente al cine como uno de los nutrientes de su obra artística, porque los medios académicos lo han subestimado como expresión artística y no han valorado del todo sus aportaciones a la cultura universal, a pesar de que Walter Benjamin planteó desde 1936 que no podía ser marginado de la teoría del arte. ${ }^{1}$

El futurismo abarcó la pintura, la literatura, el cine, el teatro dramático y de variedades, la poesía, la política, la tipografía, la música, la teoría del arte; fue un movimiento integral, a diferencia del impresionismo y del cubismo, cuya acción se circunscribió a la pintura Era una manera de ser, una sensibilidad y una actitud intelectual -como lo definió Umberto Boccionique transformó no pocos aspectos de la cultura italiana de la segunda década de este siglo. Diferenció con claridad y precisión lo nuevo de lo viejo, detectó las aportaciones técnicas, culturales y científicas de finales del siglo pasado que abrían la puerta al siglo del átomo y de la computadora, al siglo $\mathrm{XX}_{\text {. }}$

En pintura propuso el dinamismo universal, implícitamente sustentado en la cronofotografía de Marey y en los principios que animaron a los hermanos Lumière a crear el cinematógrafo; influencias que los futuristas nunca explicitaron y, por el contrario, ocultaron; pero tengo para mí que se basaran en dichos inventos para su obra plástica, aspecto que me parece no ha sido suficientemente estudiado.

\section{Los estudios sobre los futuristas, la cronofotografía y el cine}

En los estudios sobre los futuristas la cronofotografía ha sido asociada con mayor frecuencia al dinamismo; no debe extrañar puesto que en algunas pinturas, sobre todo de Giacomo Balla y de Luigi Russolo, su presencia es obvia. En cambio, por lo general omiten al cine como fuente, sobre todo los

\footnotetext{
${ }^{1}$ Walter Benjamin, "La obra de arte en su época de reproductibilidad técnica", en Discursos interrumpidos (1936), Madrid, Taurus, 1973.
} 
más antiguos; sólo recientemente lo aceptan como una posible influencia; tales estudios reflejan la aceptación paulatina del cine como agente transformador de la cultura, particularmente por las instituciones de investigación. ${ }^{2}$ El estudio más antiguo al que tuvimos acceso corresponde a Joshua C. Taylor, publicado en 1961 en Nueva York por el Museo de Arte Moderno. ${ }^{3}$ Cuestiona a los críticos que persisten en ver a los futuristas como una variante del cubismo analítico de los primeros años, con la única diferencia de que pretenden representar el movimiento, un objetivo realizado mejor en las películas.

A su juicio, el movimiento para los pintores futuristas era para ser analizado con una mentalidad moderna, para dar cuerpo a una fuerte expresión personal.

Para Taylor, el dinamismo fue la palabra mágica de los futuristas, que significaba la diferencia entre la vida y la muerte, entre la participación en un envolvente universo que se expandía y se contraía, y un aislamiento personal. El dinamismo estaba en sus corazones, era un trascendentalismo basado en un mundo nuevo. Cita a Severini:

Para centrar nuestra atención escogimos las cosas en movimiento, porque nuestra sensibilidad moderna está particularmente calificada para empunar la idea de velocidad. Pesados y poderosos automóviles corriendo a través de las calles de nuestras ciudades, bailarinas que se reflejan en el mágico ambiente de luz y color, aeroplanos volando sobre las cabezas de los excitados tumultos de gente.... Estas fuentes de emoción satisfacen nuestro sentido de un universo lírico y dramático, mejor que lo podrán hacer dos peras y una manzana ${ }^{4}$

A su juicio, los futuristas, al igual que Kandinsky, partieron de los impresionistas, aunque les interesaba pintar sobre todo las complejas relaciones recíprocas entre los objetos y su entorno; querían patentizar la acción por la influencia que ejercía ésta sobre las formas de los objetos.

Establece dos categorías de movimiento: aquellos objetos que se mueven por sí mismos, sugiriendo la fuerza centrípeta de su masa; y aquel que se mueve dentro del espacio mezclando su ritmo con otros objetos y, eventualmente, con el espacio mismo ${ }^{5}$

No establece las fuentes del dinamismo, ni mucho menos asocia a éste con el cine o con la cronofotografía, a pesar de que el mismo Museo de Arte

\footnotetext{
${ }^{2}$ Apud, Standish D Lawder, The Cubist Cinema, New York University, New York, 1975, p 7

${ }^{3}$ Joshua C. Taylor, Futurism, Museum of Modern Art, New York, 1961

${ }^{4}$ Idem, pp. 10 y ss

${ }^{5}$ Idem, p. 12 .
} 
Moderno de Nueva York, donde trabajaba, había publicado en 1946 un artículo que analizaba la influencia de Marey en el cuadro Desnudo descendiendo la escalera (figura 1), pintado en 1912 por Marcel Duchamp, que conceptualmente tiene gran semejanza con pinturas contemporáneas de Giacomo Balla (figura 2) y de Luigi Russolo (figura 3). ${ }^{6}$

En 1964, Ida Rodríguez, documentada ampliamente en manifiestos de los futuristas, estuvo cerca de asociar el dinamismo con el cine,

rebelándose contra los términos "armonía" y "buen gusto"; contra los críticos y, en general, contra los conceptos e instituciones vacías del pasado, levantaron el dinamismo a valor único y universal colocándolo dentro de la pintura como "sensación dinámica" y construyendo sus cuadros bajo un ángulo siempre móvil. Mediante una rítmica superposición de formas trataron de captar el instante en que el movimiento se desplaza. ${ }^{7}$

No está por demás plantear que la traducción literal de la palabra cinematógrafo, de la cual cine es apócope, significa escritura del movimiento.

Cuatro años después, en 1968, Marianne W. Martine, ${ }^{8}$ en el capítulo dedicado al estudio de las fuentes de la teoría de la pintura de los futuristas, omite al cine como uno de los nutrientes. ${ }^{9}$ Después de informar sobre la valoración de la máquina y del dinamismo antes del manifiesto de Marinetti, concluye que en esencia el futurismo es una adaptación de las ideas de los impresionistas y de los simbolistas franceses. ${ }^{10}$

En 1970 Umbro Apollonio establece la presencia de la cronofotografía en algunas obras de Balla y de Marcel Duchamp; en particular en Volo di rondine de Balla pintada en 1913 directamente de una fotografía del vuelo de los pájaros tomada en 1880 por Marey. ${ }^{11}$

En 1973 Max Kozloff dio un paso atrás, pues a pesar de que se propuso, cuando escribió sobre cubismo y futurismo, mostrar aquello que los artistas rechazaron y exploraron al tomar sus decisiones pictóricas, no detectó la presencia de la cronofotografia ni del cine ${ }^{12}$ en el manifiesto de la pintura futurista del 11 de abril de 1911, que cita textualmente,

${ }^{6}$ Bulletin of Museum of Modern Art, Museum of Modern Art, New York, vol. VIII, núms. 4-5, pp. 19 y ss.

'Ida Rodríguez Prampolini, El arte contemporáneo, México, Editorial Pormaca, 1964, p. 36

${ }^{8}$ Marianne W. Martine, Futurist Art and Theory. 1909-1915, Oxford, Clarendon Press, 1968

${ }^{9}$ Idem, pp. 50 y ss

${ }^{10} \mathrm{Idem}, \mathrm{p} .54$

${ }^{11}$ Umbro Apollonio, Futurist manifestos (1970), New York, The Vicking Press, 1973, p. 15

${ }^{12}$ Max Kozloff, Cubism/Futurism, New York, Carterhouse Press, 1973, p. X 
Il gesto, per noi, non sara più un momento fermato del dinamismo universale: sara decisamente, la sensazione dinamica eternata como tale.

Tutto si muove, tutto corre, tutto volge rapido. Una figura non è mai stabile davante a noi $[\ldots . . .]^{13}$

Muchas de las imágenes sugeridas en este manifiesto fueron pintadas por los futuristas el siguiente año. Es significativo que primero concibieran sus sujetos y luego trataran de incorporarlos a la "sensación dinámica" [.... $]^{14}$

No, no era extraño, puesto que primero tuvieron frente a sí los álbumes fotográficos de Marey y literatura cinematográfica, ambos de amplia circulación en publicaciones especializadas, para redactar el manifiesto, como lo veremos adelante.

Pese a comparar la pintura futurista con el acto de fotografiar y pese a la terminología usada en el manifiesto, Kozloff no intuye la presencia del cine, a pesar de detectar los esfuerzos de Boccioni y de Carlo Carrà por imprimir movimiento a las figuras de sus pinturas La città che sale (il lavoro), de Boccioni y Funeral dell'anarchico Galli de Carrà, pintadas en 1910 después de la redacción del Manifiesto técnico de la pintura futurista, donde trataron de aplicar el dinamismo:

It would be difficult to say which of this exciting paintings, Boccioni's or Carrà's, renders the more vivid sensation of dynamic energy. One painter marries that energy to light and makes of it a fireworks display articulated with delicacy; the other identifies it with the empathetic capacity of our own muscles to tatuen at a spectacle of furious human struggle. Both works, in any event, exalt motion as an absolut. Not only is the subject in continuous, intoxicated motion, but the activity engulfs the spectator, forcing him to recognize the ever-restless momentum of perception itself. ${ }^{15}$

En 1975 Standish Lawder ${ }^{16}$ reconoció la presencia del cine y de la cronofotografía en la pintura de los futuristas en dos aspectos: en el principio de captar el movimiento y en los experimentos de Muybridge y Marey para estudiar la locomoción de los animales, que contribuyeron a resolverles el problema de la representación plástica del dinamismo. Sin embargo, su

\footnotetext{
${ }^{13}$ Kozloff lo traduce al inglés. Preferí transcribir el texto original con subrayados tomado de Il futurismo, de Raffaele Carrieri, Milano, Edizioni del Millione, 1961, p. 30.

${ }^{14}$ Kozloff, op cit, , pp. 147-148.

${ }^{15}$ Kozzlof, op cit., p. 147.

${ }^{16}$ Lawder, op. cit.
} 
explicación no es suficientemente clara porque el capítulo en el que habla de los futuristas lo dedica al estudio de los antecedentes del filme de vanguar dia de años posteriores.

Por último, en 1977, en Londres, para Caroline Tisdall ${ }^{17}$ el dinamismo universal llevaba aparejados un legado de la filosofía de Nietzsche y de Bergson, una aproximación intuitiva a los simbolistas y resultados de las exploraciones de las relaciones entre la mente y la materia: "ni el análisis del movimiento, ni capturar un simple movimiento, les satisfacía" porque sería repetir lo que había hecho la cronofotografía de E.J. Marey y Eadweard Muybridge, o el cinematógrafo. La fuente de la representación visual del dinamismo la encuentra en las figuras de Medardo Rosso sacudiéndose y meciéndose en un autobús, así como en los rayos de sol de las pinturas de Previati; "de esas simples fórmulas cada pintor tomó los aspectos que más le interesaban. Para Balla fue sobre todo un simple fenómeno óptico", lo ejemplifica con Lámpara de luz y Muchacha corriendo al balcón, entre otros. No asocia las imágenes pictóricas con las imágenes de la cronofotografía, a pesar de citar el Desnudo descendiendo la escalera, de Marcel Duchamp.

\section{El movimiento y la velocidad en el futurismo}

Cuando Marinetti fundó el futurismo en febrero de 1909, el dinamismo, la cronofotografía y el cine todavía no cruzaban por su mente, si nos atenemos al manifiesto que dio a conocer sus propuestas, plenas de violencia e iconoclasia:

deseamos liberar a este país de su fétida gangrena de profesores, de arqueólogos, de guías de turista y de anticuarios [...] deseamos destruir los museos, las bibliotecas, las academias de cualquier tipo, y combatir al moralismo, al feminismo y la cobardía oportunista y utilitaria. ${ }^{18}$

Subrayaba el movimiento y la velocidad, como características de la vida contemporánea:

Queremos exaltar el movimiento agresivo, el insomnio febril, la carrera, el salto mortal, la bofetada y el puñetazo. ${ }^{19}$

${ }^{17}$ Caroline Tisdall, Futurism, London, Thames and Houdson, 1977

${ }^{18}$ Filippo Tommaso Marinetti, Manifiesto de la fundación del futurismo, en Raffaele Carrieri, op. cit, p. 12 
Afirmamos que la magnificencia del mundo ha sido enriquecida por una nueva belleza: la belleza de la velocidad. Un automóvil de carrera con su cofre adornado de gruesos tubos semejantes a serpientes de aliento explosivo... un automóvil rugiente, que corre sobre el asfalto, es más bello que la Victoria de Samotracia.

Deseamos alabar al hombre que tiene el volante, cuya asta ideal atraviesa la Tierra, lanzada a una carrera, ella misma, sobre el circuito de su órbita [....]

[....] el tiempo y el espacio murieron ayer. Vivimos ya en el absoluto, porque ya hemos creado la eterna velocidad omnipresente.

[....] Cantaremos [....] a las locomotoras de amplio pecho que patalean sobre los rieles, como caballos de acero embridados de tubos, y al vuelo deslizante de los aeroplanos, cuya hélice chilla al viento como una bandera y parece aplaudir como una muchedumbre entusiasta. ${ }^{20}$

La poesía era el medio adecuado para aplicar los principios que daba a conocer; no hablaba de otro medio de expresión. ${ }^{21}$

Más que establecer las características de su poética (lo haría más tarde), el manifiesto era una declaración de principios.

Como el manifiesto lo publicó un diario parisino, tuvo un impacto internacional casi inmediato, no se diga dentro de Italia, donde un grupo de cinco pintores, Umberto Boccioni, Carlo Dalmazzo Carrà, Luigi Russolo, Giacomo Balla y Gino Severini, un año después de la fundación del futurismo, el 11 de febrero de 1910, publicaron un manifiesto sobre la pintura en el que se adherían a Marinetti. ${ }^{22}$

Se dirigían a los artistas jóvenes de Italia. Renegaban, al igual que Marinetti, de la tradición, del academicismo, de los museos, de las galerías, de la religión, de la crítica. Deseaban renovar todas las expresiones del arte mediante la destrucción del culto al pasado, de la obsesión por lo antiguo, de la pedantería y del formalismo académico; decían despreciar toda forma de imitación, pero a la vez exaltaban toda forma de originalidad, por temeraria y violenta que fuese; ${ }^{23}$ más que propuestas de aplicación pragmática, también su manifiesto era una declaración de principios.

Al igual que Marinetti, aluden a la velocidad y al movimiento:

\footnotetext{
${ }^{20}$ Idem.

${ }^{21}$ Idem, p. 11

${ }^{22}$ Idem, pp. 26-27

${ }^{23}$ Idem
} 
Debemos inspirarnos en los tangibles milagros de la vida contemporánea, en la férrea red de velocidad que envuelve a la Tierra, en los transatlánticos, en los acorazados, en los vuelos maravillosos que surcan los cielos, en las audacias tenebrosas de los navegantes submarinos, en la lucha espasmódica por la conquista de lo desconocido ${ }^{24}$

Dos meses después, el 11 de abril de 1910, en el Manifiesto técnico de la pintura futurista, plantean, por fin, el dinamismo como objetivo principal de la pintura:

El gesto para nosotros no será más un momento congelado del dinamismo universal: será, decididamente, la sensación dinámica eternizada como tal.

Todo se mueve, todo corre, todo gira rápido. Una figura nunca está estable frente a nosotros, aparece y desaparece incesantemente. Por la persistencia de la imagen en la retina, las cosas en movimiento se multiplican, se deforman, sucediéndose, como vibraciones que recorren el espacio. Así, un caballo al galope no tiene cuatro patas: tiene veintey sus movimientos son triangulares [...] Las 16 personas que hay en torno nuestro, en un tren que corre, son una, diez, cuatro, tres; están paradas y se mueven; van y vienen, rebotan sobre la calle, devoran una zona de sol, vuelven a sentarse; símbolos persistentes de la vibración universal. ${ }^{25}$

El primer párrafo alude a la fotografía instantánea, base del cine, puesto que la sensación de movimiento en éste la comunica la sucesión rápida de fotografías de diversos instantes de un movimiento. El segundo párrafo se refiere al objetivo cinematográfico de captar el movimiento. En otras palabras, la experiencia cinematográfica respalda su concepto de dinamismo universal.

El texto de la cita indica también que los pintores, con seguridad preocupados por la representación del movimiento y de la velocidad, habían investigado y descubierto los estudios del movimiento llevados a cabo por Marey y los artículos sobre las primeras películas de los hermanos Lumière publicados en Francia en La Nature, Revue des Sciences et de leurs applications aux arts et à l'industrie, particularmente "Le cinématographe de MM. Auguste et Louis Lumière", que describen los objetivos del cinematógrafo y $L a$ llegada del tren, película filmada en 1895, a la que parecen referirse en el manifiesto. ${ }^{26}$

${ }^{24}$ Idem, p. 26.

${ }^{25} \mathrm{Idem}, \mathrm{p} .30$.

26 "Le cinématographe de MM. Auguste et Louis Lumière", La Nature. Revue des Sciences et de leurs applications aux arts et à l'industrie, Paris, G. Masson, éditeur, 1895, deuxième semestre, pp. 215-218. 
La frase "por la persistencia de la imagen en la retina" la tomaron de dicho artículo, ${ }^{27}$ distribuido por los enviados de los hermanos Lumière como boletín de prensa en las primeras sesiones en cada país que visitaban. Transcribo fragmentos del texto publicado en México:

[...] la banda y las imágenes que lleva [el aparato] quedan inmóviles durante los dos tercios del tiempo, el otro tercio se emplea en la progresión de dicha banda, durante este intervalo se interrumpe la proyección de rayos luminosos, y mediante la persistencia de las impresiones en la retina [el subrayado es mío], que dura un vigésimo de segundo, el ojo percibe una serie de impresiones luminosas, que le causan la perfecta ilusión de cuerpos en movimiento $[\ldots . .]^{28}$

La referencia al caballo la toman de los álbumes de Eadweard Muybridge ${ }^{29}$ y de Jules Etienne Marey, del primero publicado en 1887, y los del segundo en 1889,1892 y 1899, Le mouvement, La photographie du mouvement y La chronophotographie, respectivamente.

Desde luego que los experimentos de Muybridge de secuencias de imágenes fijas de diversas fases del movimiento del caballo se reflejaron en la plástica de su época, sobre todo en lienzos de tema histórico, porque contribuyeron a solucionar la representación de la postura de los caballos en movimiento. ${ }^{30}$

Marey intentó fotografiar todas las fases del movimiento. Con sus exposiciones múltiples creó una síntesis del mismo en el tiempo y en el espacio, al mismo tiempo que un análisis en hileras de imágenes, con un novedoso efecto visual, porque ya no eran imágenes instantáneas, sino imágenes agobiadas por el movimiento, en las que no era claramente visible la fase individual porque sus contornos quedaban borrados por la superposición de exposiciones. Imágenes sugestivas que desde luego tuvieron su impacto en pintores como Degas y Seurat, por decir unos nombres ${ }^{31}$ (figura 4).

Continúan los futuristas:

La ciencia de hoy, negando su pasado, responde a las necesidades intelectuales de nuestro tiempo. Nuestra nueva conciencia no considera más al hombre como

27 Idem.

28 "La novedad del día en México. El cinematógrafo Lumiére", El Mundo, domingo 23 de agosto de 1896, pp. 118-119.

${ }^{29}$ Vide Anita Vera Mozley et al, Eadweard Muybridge: The Stanford Years, 1872-1882, Los Angeles, Stanford University Museum of Art, 1973.

${ }^{30}$ Para mayores detalles, ver el libro citado en la nota anterior.

${ }^{31}$ Idem, p. 98 . 
centro de la vida universal. El dolor de un hombre es interesante para nosotros, tanto como el de una lámpara eléctrica, que sufre y ansía y grita con las más desgarradoras expresiones de color; la musicalidad de las líneas de los pliegues del vestido moderno tienen para nosotros una potencia emotiva y simbólica igual a la que tenía el desnudo para los antiguos. ${ }^{32}$

El artículo de los hermanos Lumière menciona también a la electricidad:

El ingenioso y complicado mecanismo del aparato hace que la banda, al desenrollarse, vaya a presentar una imagen delante de una abertura cada quinceavo de segundo; esta abertura es atravesada por un haz luminoso de poderosa intensidad $[\ldots . .]^{33}$

El haz de rayos luminosos que emana del aparato, visible en la oscuridad de la sala a cualquier persona, adquiere forma cónica en su camino a la pantalla; y parece chillar, y gritar; cobra vida y adquiere perfil con el ascenso y descenso de las impurezas del aire que lo cruzan, sobre todo el humo de los fumadores clandestinos. Los futuristas traducirían la forma cónica del haz luminoso a valores tipográficos, como lo veremos en su oportunidad.

Regresando al artículo de los hermanos Lumière, leemos que

A poco que la fotografía había progresado lo bastante para producir instantáneas, los sabios se propusieron emplearla con objeto de fijar escenas fugitivas, que luego pudieran ser objeto de estudio y meditación; así es como en 1874 Janssen se sirvió de su revólver fotográfico para la observación del paso de Venus por el disco del sol; y Muybridge, de San Francisco, Cal , obtuvo en la misma época series de fotografias de objetivos cuyos obturadores se levantaban a intervalos regulares por aparatos ingeniosos que movía la electricidad. Desde esa época, el célebre fisiólogo Mr. Marey ha veñido utilizando la cronofotografia para el estudio de la locomoción animal, del vuelo de las aves y otros fenómenos fisiológicos. Estos y otros autores que en el asunto se han ocupado se dedicaron todos a obtener pruebas sucesivas en número restringido, haciendo la descomposición o el análisis del movimiento, pruebas que estudiaban después la reconstitución de las síntesis del movimiento ${ }^{34}$

Agregaba que el camarógrafo podía acelerar a su voluntad el ritmo de la proyección para analizar, sintetizar, descomponer, dividir o multiplicar las

${ }^{32}$ Carrieri, op. cit, p 30

${ }^{33} \mathrm{El} \mathrm{Mundo,} \mathrm{op} \mathrm{cit.}$

${ }^{34}$ La Nature, El Mundo, op cit. 
fases del movimiento para su estudio minucioso, lo cual constituía un paso adelante de los experimentos de Marey.

En 1912, en el catálogo de la exposición de los futuristas en París, Londres y Florencia, pormenorizan su inquietud por el movimiento, aunque matizada por la teoría de los estados de ánimo de Boccioni, propuesta después del Manifiesto técnico:

En nuestro manifiesto habíamos declarado que se necesitaba dar la sensación dinámica, por lo tanto el ritmo particular de cada objeto, su tendencia, su movimiento, o, mejor dicho, su fuerza interna.

Se tiene la costumbre de considerar al ser humano bajo sus diversos aspectos de movimiento o de calma, de agitación alegre o de gravedad melancólica.

Pero nadie se da cuenta de que todos los objetos considerados inanimados revelan, en sus líneas, la calma, la locura, la tristeza o la alegría. Estas tendencias tan diversas dan a las líneas de que están formados un sentimiento y un carácter de pesada estabilidad o de aérea ligereza.

Cada objeto revela, por medio de sus líneas, como si se descompusiera según las tendencias de sus fuerzas.

Esta descomposición no tiene leyes fijas; varía según la personalidad característica de cada objeto y según la psicología y la emoción del que lo mira. ${ }^{35}$

No debe causar extrañeza que los futuristas descubrieran a Marey y a los principios que animaban al cinematógrafo, a pesar de mediar de 20 a 15 años, respectivamente, entre tales experimentos y los futuristas. En primer lugar porque ambos inventos reunían las características de su búsqueda: productos de la ciencia relacionados con el movimiento, la velocidad, la electricidad; no tenían pasado ni tradición artística que los atara; en segundo, Giacomo Balla había estudiado fotografía y había sido maestro de Umberto Boccioni y Gino Severini al abrir el siglo veinte. De los cinco pintores firmantes del manifiesto, Balla era el mayor: en 1910 contaba 39 años de edad y 20 de pintar.

Balla nació en Turín en 1871; era un adolescente cuando Marey llevaba a cabo sus experimentos, y tenía 25 años cuando el cine se dio a conocer en

\footnotetext{
${ }^{35}$ Giorgio de Marchis, Giacomo Balla L'aura futurista, Torino, Giulio Eunadi editore, 1977, pp. $97-98$
} 
Italia en 1896, mientras que los otros cuatro firmantes eran adolescentes cuando la mente se impresiona por lo novedoso: Carrà contaba 15 años, Boccioni, 14; Severini, 13; y Russolo apenas 11.

Casual o intencionalmente, ese año de 1896 Balla frecuentó en Turín el estudio fotográfico de Orestes Berportante. ${ }^{36}$

Pese a su edad, Balla se afilió al futurismo sin duda porque satisfizo su búsqueda individual y aislada de renovación formal y temática de la pintu$\mathrm{ra}^{37}$ según se observa en su obra. En 1901 pintó $I l$ lavoro y en 1903, Il fallimento, entre otras, sin la presencia de la figura humana. En la primera, un poste de luz eléctrica es propiamente el sujeto, mientras que en la otra las paredes, las puertas y la banqueta atraen la atención. Corresponden a su búsqueda "verista" según las propuestas de Emilio Zola para la literatura naturalista, y a la búsqueda de la luminosidad de los impresionistas. En $L a$ giomata del operaio de 1904 (figura 5), rompe la composición tradicional al dividir el espacio rectangular en dos partes. La primera mitad a su vez la seccionó en dos; de esa manera partió en tres la vista de un edificio en construcción. La primera mitad, seccionada en dos, mostraba dos aspectos diurnos del edificio, la superior con los obreros en el trabajo y la inferior mientras comían. La segunda mitad mostraba una vista nocturna de la parte trasera del mismo edificio, naturalmente sin los trabajadores; sólo los andamios nos recuerdan su presencia. Habia una ruptura espacio-temporal novedosa para la época. Balla bautizó a cada una de las secciones: trabajando, comiendo y regreso [a casa].

En Salutando (figura 6) de 1905, tres señoras, al descender una escalera en espiral, hacen un alto para voltear hacia el pintor para saludarlo. Al parecer Balla copió una instantánea; en su cuadro tomó el lugar del fotógrafo. La profundidad de la espiral de la escalera comunica la sensación dinámica, basada en imágenes cronofotográficas de Marey, que pintará después.

Encontrados los principios, quedaba el problema de la representación plástica del movimiento y de la velocidad. Es verdad que el cine reproducía a las personas y a los objetos en movimiento, pero sólo es una ilusión óptica, pues no es más que la sucesión de diversas fotografías fijas que muestran varios instantes de la trayectoria de un movimiento, exhibidas una tras otra, de tal manera que la ilusión del movimiento es producto de "la persistencia de la imagen en la retina”. Aisladas no producen la sensación dinámica buscada por los futuristas; son como cualquier fotografía instantánea.

${ }^{36}$ Idem, p 5

${ }^{37}$ Idem, p. 3 
En cambio, la cronofotografía de Marey comunicaba la sensación de dinamismo al mostrar, en una misma imagen, el desdoblamiento minucioso de las fases sucesivas del desplazamiento de los objetos y cuerpos en movimiento.

Los futuristas, reacios a copiar fotográficamente cualquier cosa, tomaron sólo como punto de partida el principio cinematográfico de la reproducción del movimiento y las imágenes cronofotográficas para la representación plástica.

Para la traducción de esos principios a la pintura, los futuristas disponían en primer lugar de los colores. En aquellos años, en cine y fotografía, salvo iluminando a mano cuadro por cuadro, o cada una, era imposible la reproducción del color. Por otra parte, los pintores podían agregar ángulos y matices no captados por la cámara, mediante recursos utilizados por los pintores cubistas, aunque los futuristas negaran también su influencia.

Era, pues, absolutamente cierto que entre los resultados plásticos de los inventos mencionados y las pinturas de los futuristas no había nada en común, por ser esencialmente diferentes, como sostenían los futuristas.

El dinamismo era la representación pictórica del movimiento y de la velocidad, para lo cual los futuristas educaron su vista; de ahí que sea cierta la frase acuñada por Roger Allard de que "todos llevaban una cámara de cine en la panza". 38

El impacto de los inventos mencionados en unos es más claro que en otros. En Balla y Russolo es más que evidente. En Boccioni lo apreciamos en Le forze di una strada (1911), en Stati d'animo I, II y III (1911); en Carrà en Cavallo e cavaliere (1912); en Russolo en Compenetrazione di case+luce+cielo (1913) y en Solidità della nebbia (1912); en Balla en Dinamismo di un cane al guinzaglio (1912), en Bambina che corre sul balcone (1912); en Severini en Danzatrice in blu (1912) y en Danzatrice al tabarin (1912), sólo por mencionar obras que no permiten la duda; pero sin temor a equívoco se puede afirmar que Marey y el cinematógrafo permean toda la obra de los pintores futuristas.

Para estos años de 1912 no era aislada la utilización del cine como fuente para las artes visuales; también sirvió de punto de partida al abstraccionismo de Vassily Kandinsky, quien se inspiró en las películas científicas de Jean Comandon, producidas y distribuidas por Pathé Frères en prácticamente todo el mundo, que mostraban vistas microscópicas de una gota de sangre, de los microbios en una gota de agua, el contenido de una gota de saliva, etcétera ${ }^{39}$

\footnotetext{
${ }^{38}$ Lawder, op. cit., p. 7 .

${ }^{39}$ Idem, pp 16-17.
} 
Como era de esperar, la presencia del cine la encontramos no sólo en la pintura de los futuristas, también en la fotografía, en la tipografía y en el cine mismo. Gradualmente lo tomaron por asalto, hasta proponer una teoría cinematográfica novedosa.

\section{Fotodinamismo, dinamismo y cine}

Anton Giulio Bragaglia, joven inquieto que seguía con interés a los futuristas, hijo del ingeniero Francesco Bragaglia, director general en 1909 de la empresa Cines de Roma y constructor de los estudios cinematográficos de la misma compañía, ${ }^{40}$ dictó la conferencia Fotodinamismo en 1911 en Roma, en la que se adhería a las propuestas de los pintores futuristas. ${ }^{41}$

Conocedor, sin duda, de la obra de Marey y del cine, percibió la presencia de ambos en el manifiesto técnico. En su conferencia citó a la fotografia, a la cronofotografía y al cinematógrafo, aunque a su fotodinamismo lo hizo partir de la negación de los principios que animaban a esos inventos.

En el primer párrafo del texto, publicado en una segunda edición en 1913, dice:

el fotodinamismo no se debe interpretar como una innovación aplicable a la fotografía en el sentido que lo fue la cronofotografía. El fotodinamismo es una creación encaminada a llevar a cabo ideales que son absolutamente contrarios a los objetivos de todas las maneras de representación en la actualidad Si se le puede asociar con la fotografía, con la cinematografía y la cronofotografía, es solamente en virtud del hecho de que, como ellos, tiene sus orígenes en el vasto campo de la ciencia fotográfica. Los recursos técnicos forman una base común. Todos ellos se basan en las propiedades físicas de la cámara ${ }^{42}$

Habla de la relación del fotodinamismo con el cine. Dice que no le interesa la reconstrucción precisa del movimiento, que la cuestión de la relación entre el cine y los futuristas era absolutamente idiota porque aquél no traza la forma del movimiento, sólo lo subdivide, mecánicamente, desintegrándolo, desmenuzándolo sin ninguna clase de preocupación por el ritmo. A su juicio, el cine nunca analiza ni sintetiza el movimiento; solamente reconstruye fragmentos de la realidad. En cambio, el fotodinamismo lo analizaba en todos sus detalles ${ }^{43}$

\footnotetext{
${ }^{40}$ María Drudi Gambillo y Teresa Fiori, Archivi del futurismo, Roma, De Luca Editore, 1962, vol. II, p. 499

${ }^{41}$ De Marchis, op cit, p. 25

${ }^{42}$ Apollonio, op cit, p. 38

${ }^{43} \mathrm{Idem}$
} 
Pero el cine subyacía en los principios de análisis, síntesis y descomposición del movimiento. Bragaglia al parecer tenía en su mente el concepto de filme, no el de cinematógrafo; esto es, el cine había cambiado notablemente desde que los Lumière lo habían dado a conocer como un aparato para el estudio del movimiento, y desarrollaba vertiginosamente una narrativa peculiar que no tenía nada que ver con la intención primigenia. A lo anterior quizá se deba la afirmación de Bragaglia de que los futuristas nada tenían que ver con el cine

A juicio de Bragaglia la cronofotografía tampoco analizaba el movimiento, sólo era una variante de la cinematografía que, en una imagen o en una sucesión de imágenes, trataba de reproducir el movimiento. Cronofotografía y fotodinamismo eran diferentes; cada uno poseía sus propias cualidades. ${ }^{44}$

Agregaba que el fotodinamismo podía desmenuzar mayormente el movimiento; lo que no era cierto porque una cronofotografía fijaba diversas fases del movimiento de un objeto; pero como la cámara utilizada por Marey sólo tenía una sola velocidad, sus ensayos eran homogéneos, casi iguales. En cambio, cuando Bragaglia publicó sus propuestas, la técnica fotográfica se había perfeccionado y podía captar con mayor precisión las diversas posiciones de los cuerpos al efectuar los movimientos, al dar mayor o menor tiempo de exposición; de ahí que Bragaglia dijese que cronofotografía y dinamismo eran diferentes. No lo eran tanto, y en resultados plásticos había pocas diferencias.

Incluso al comparar los estudios de Balla para pintar figuras en movimiento, basados en fotografías tomadas por Bragaglia, con los estudios de Marey basados en su cronofotografía, no encontramos una diferencia notable; son casi iguales, al grado de que una persona no conocedora de la diferencia básica de la velocidad impresa a la película por segundo los confundiría. Así que, en conclusión, los principios de la cronofotografía y de la cinematografía de analizar y sintetizar el movimiento eran los mismos que animaban al fotodinamismo de Bragaglia, aunque no lo admitiera.

Bragaglia como fotógrafo es poco imaginativo en relación a las aportaciones pictóricas del dinamismo, pues la única variante de sus fotografías con respecto a las de Marey es la velocidad de la cámara e, incluso, algunas fotografiäs, más que logros, las veo como fracasos: la de Balla frente a su pintura Dinamismo di un cane al guinzaglio (1912) (figura 7) no manifiesta un dominio de la técnica: movió la cámara, en lugar de que Balla fuese el que se moviera para lograr un efecto visual idéntico al de las figuras del cuadro.

${ }^{44}$ Idem, p. 39 


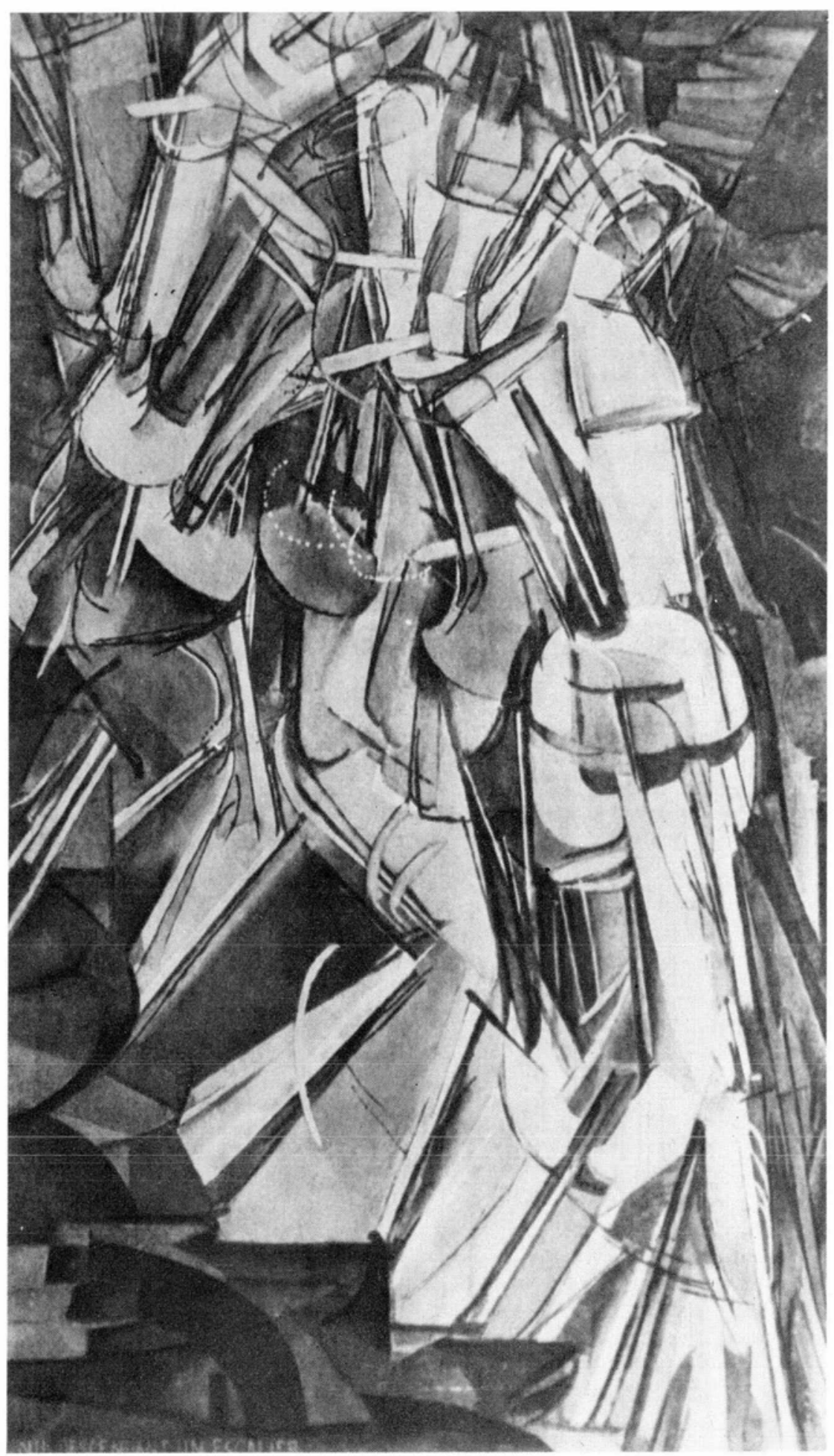

1. Marcel Duchamp, Desnudo descendiendo la escalera (1912). 


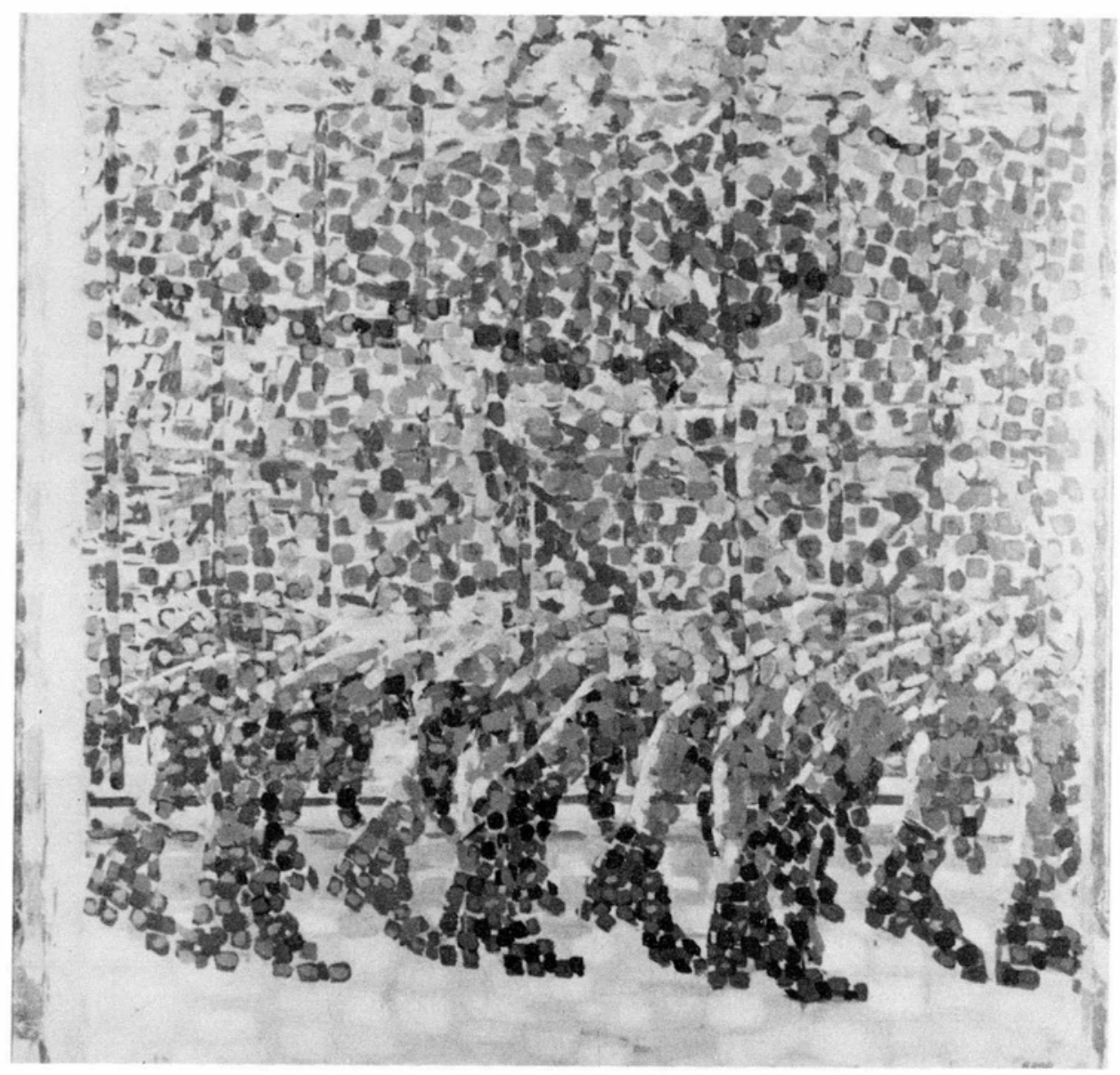

2. Giacomo Balla, Bambina che corre sul balcone (1912). 
DOI: http://dx.doi.org/10.22201/iie.18703062e.1993.64.1673

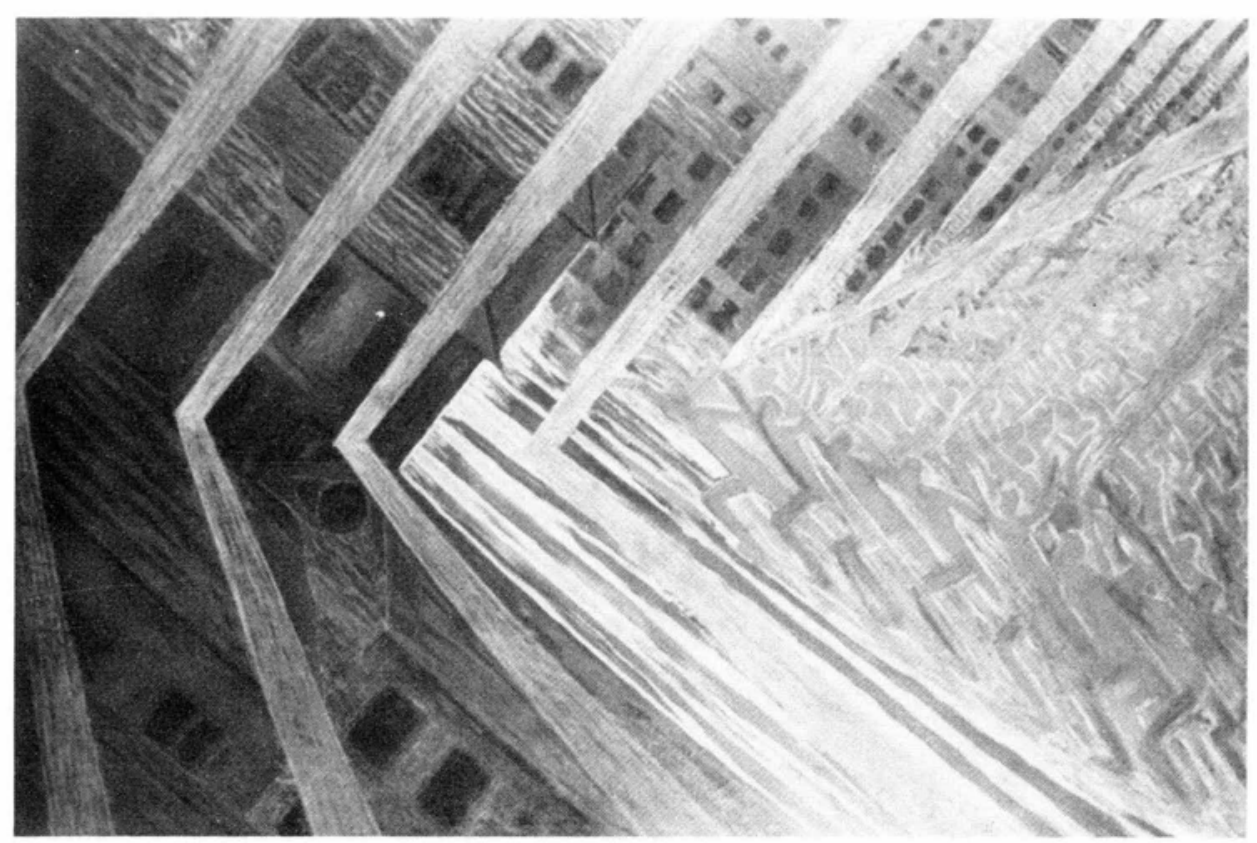

3. Luigi Russolo, La rivolta (1912). 
DOI: http://dx.doi.org/10.22201/iie.18703062e.1993.64.1673

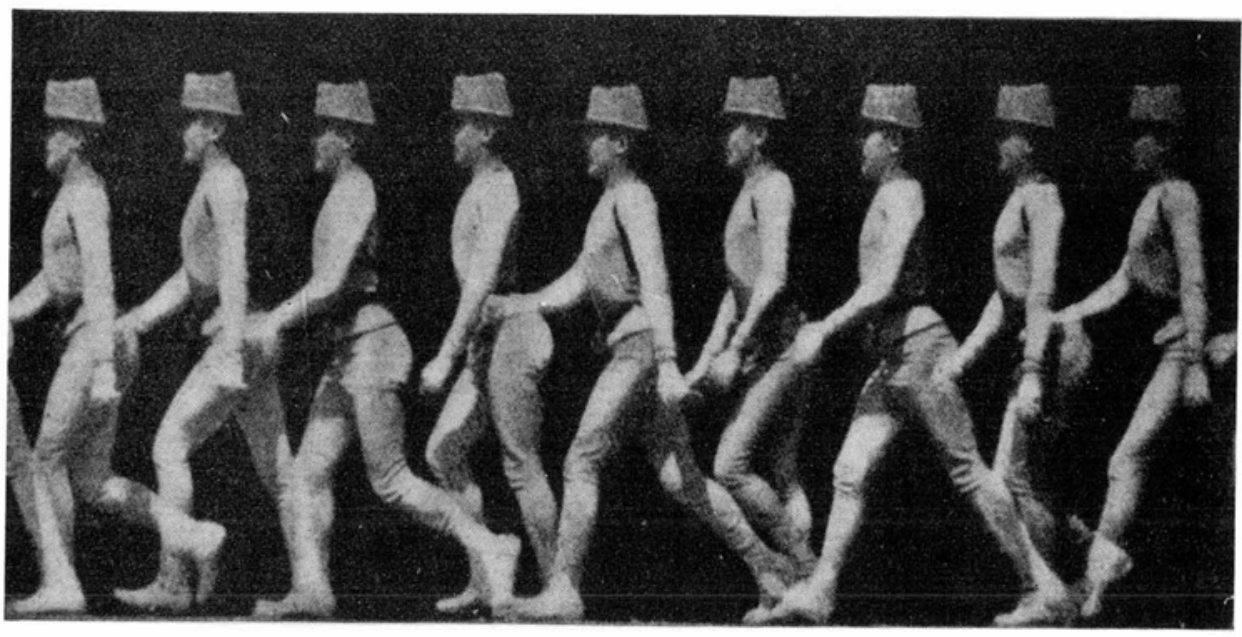

4. Demey, cronofotografía. 
DOI: http://dx.doi.org/10.22201/iie.18703062e.1993.64.1673

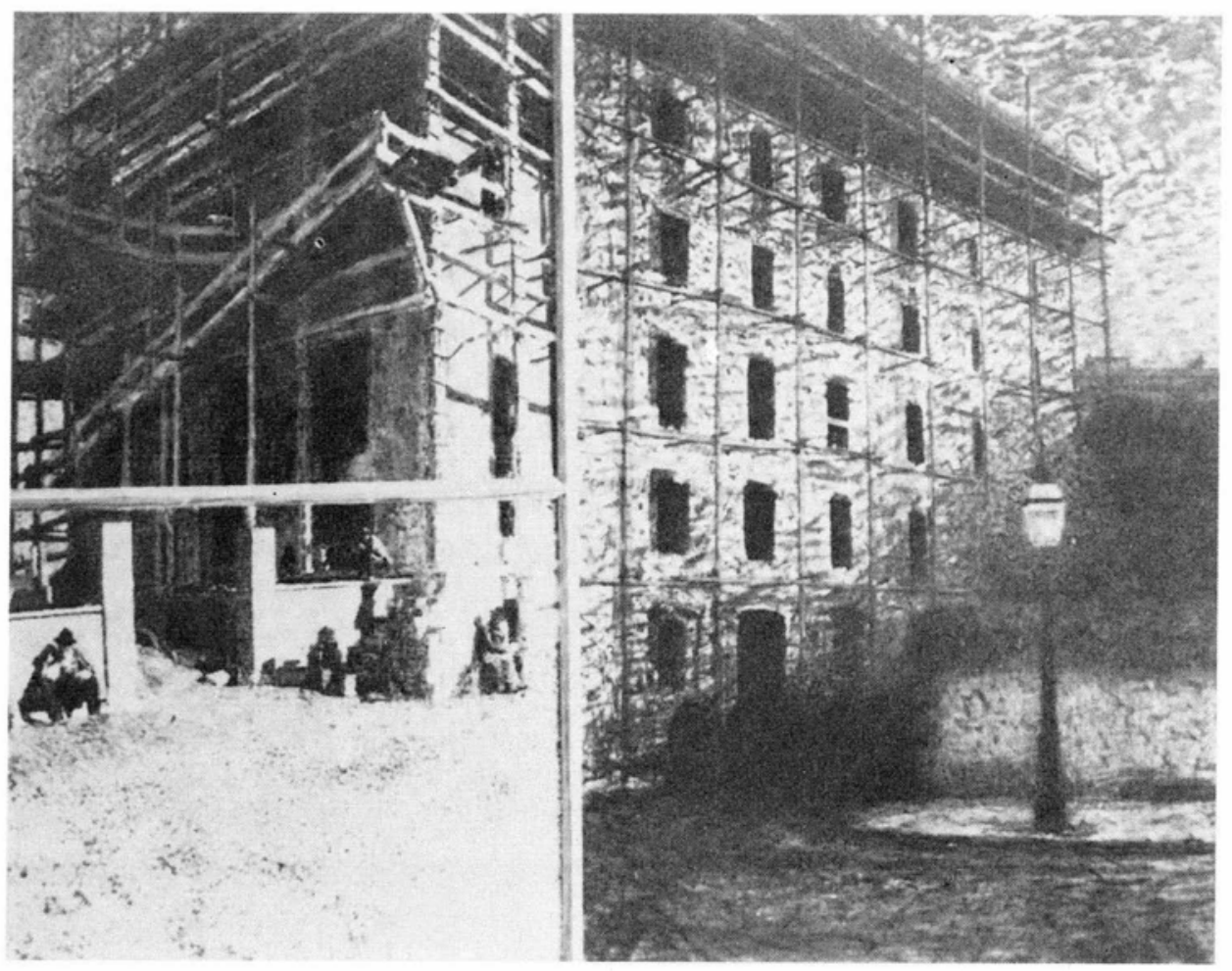

5. Giacomo Balla, Lavore (1904). 
DOI: http://dx.doi.org/10.22201/iie.18703062e.1993.64.1673

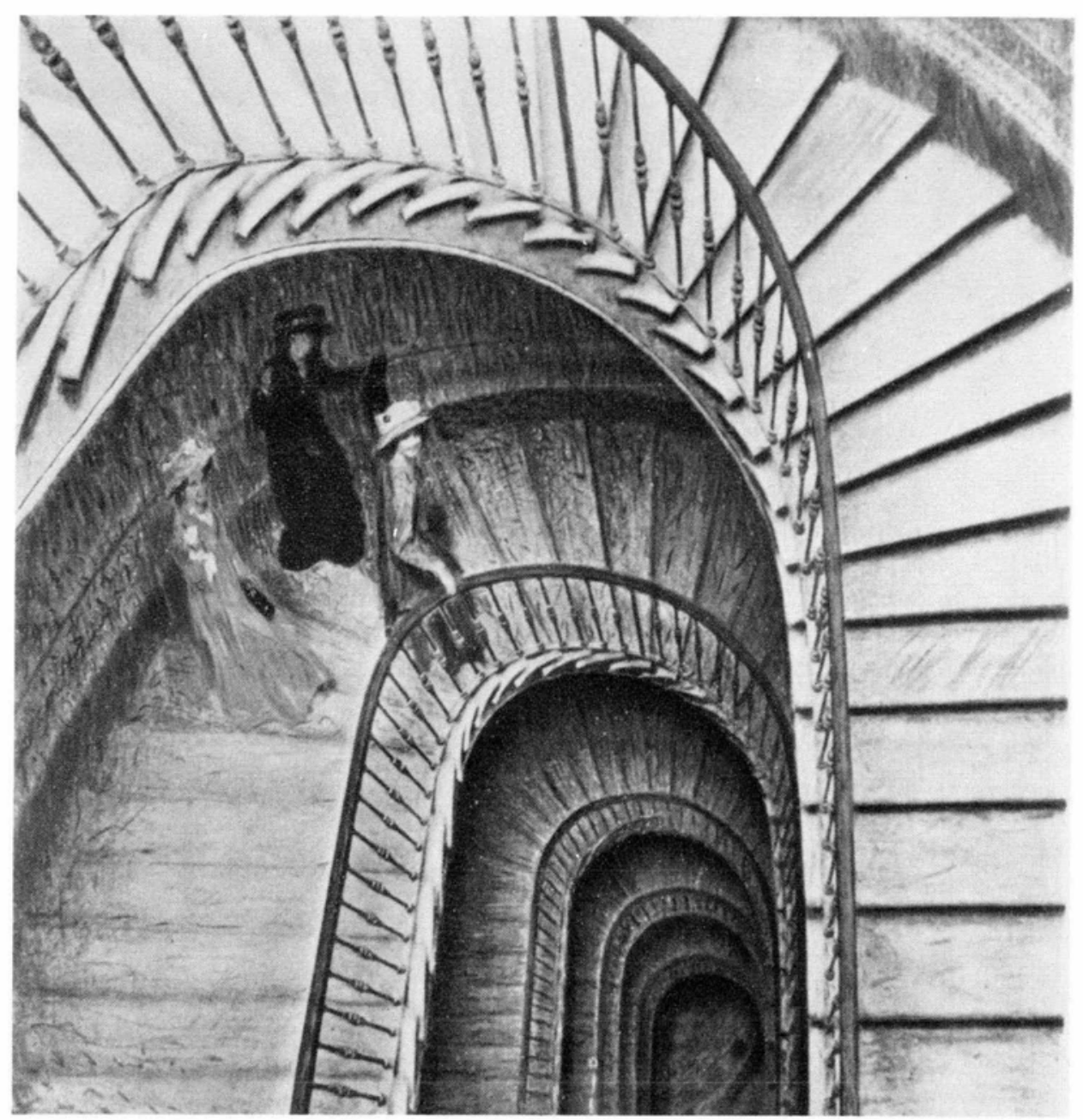

6. Giacomo Balla, salutando (1905). 
DOI: http://dx.doi.org/10.22201/iie.18703062e.1993.64.1673

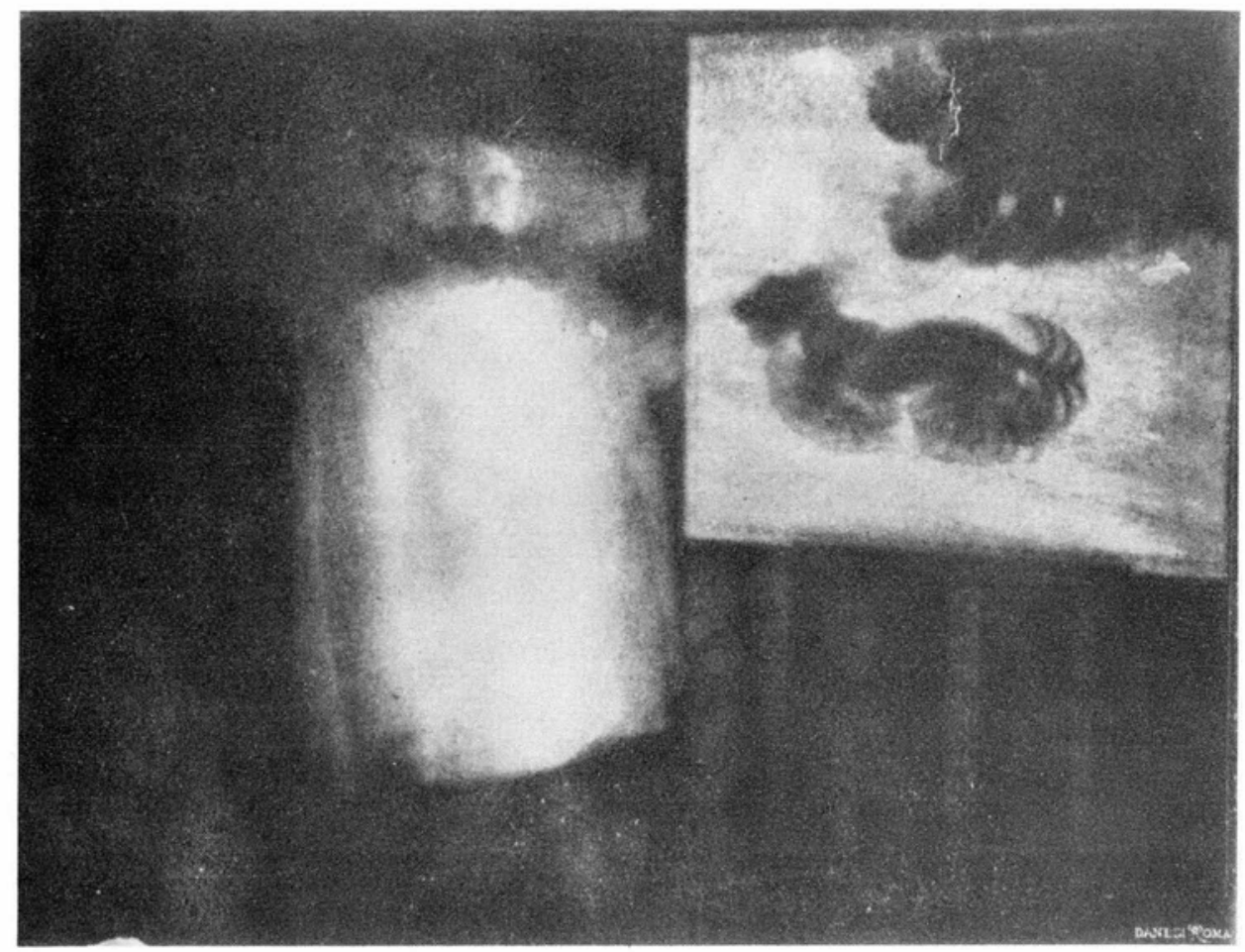

7. Anton Giulio Bragaglia, Balla frente a su pintura (1912). 
Aux heures et aux demies.

Le matín de 10 à 11 h. 1/2; l'après-midide $2 \mathrm{~h}$ à 6 h.1/2 Le soir de $8 \mathrm{~h}$. à $11 \mathrm{~h}$.

\section{LE Cinematographe LUMIERE}

GRAND CAFÉ

14, Boulevard des Capucines, 14 PAR IS

Cet appareil, inventé par MM. Auguste ct Louis Lumière, permèt de recueillir, par des séries d'epreuves instantanées, tous les mouvements qui, pendant un temps donné, se sont succédé devant l'objectif, et de reproduire ensuite ces mouvements en projetant, grandeur naturelle. devant une salle intière leur's inages sur un êran.

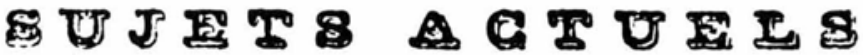

1 Sortie de l'lisine LUMIERE

a Lyon.

2 Querelle de bébés

3 Bassin des Tuileries.

4 Le train.

5 L $\theta$ régiment.
6 Maréchal-Ferrant.

\% Partio d'écarté.

8 Mauvaises herbos.

9 Lo mur.

10 La mer.

La Direction se réserve le droit, en cas de force majaure. de remplacer un des Tableaux porté au programnie par un autre.

LE CinÉmatographe peut fonctionner dans les Salons.

8. Programa de las primeras funciones de cine en París. 


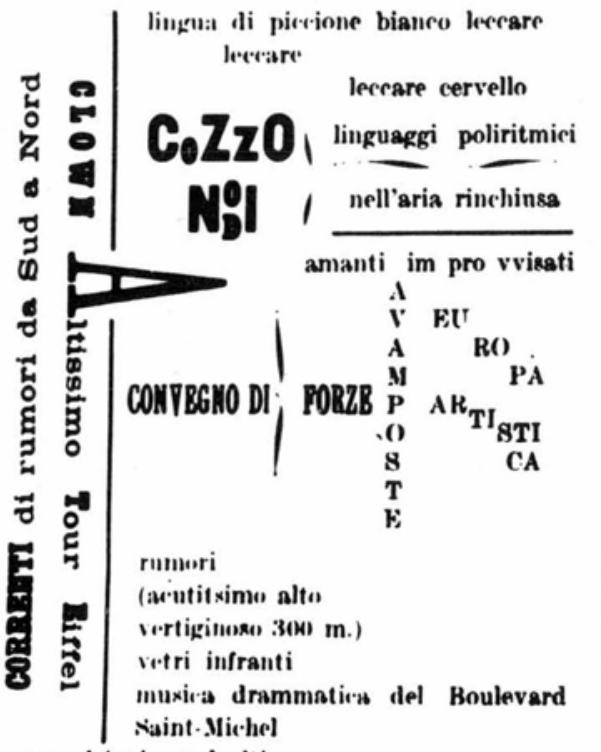

wonpmsizinni a velocits

whitelture (fuggente sferice elliavoldale fut(III)I+)

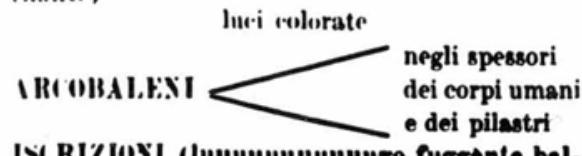

IN RI\%IIISI (luuuunuuuuungo fuggente balzunte intrecciates bianco su fondo celeste)

\section{nowratoses}
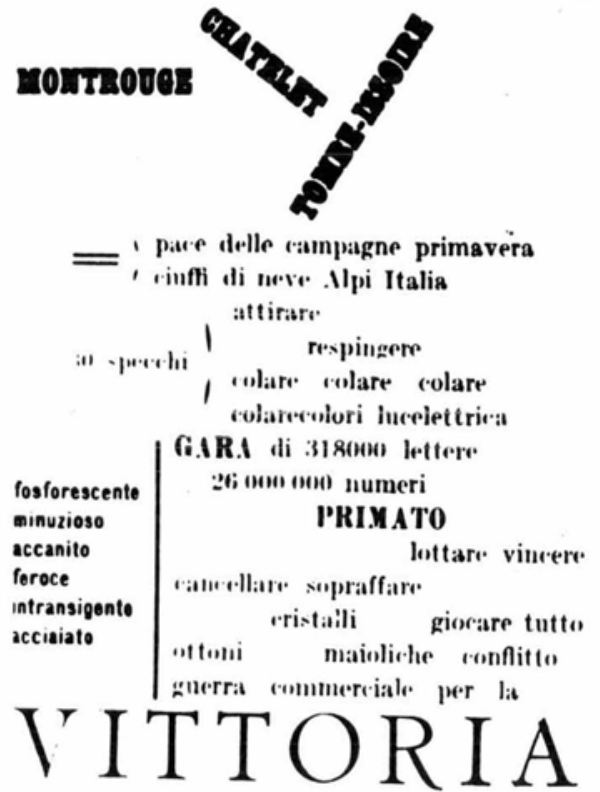

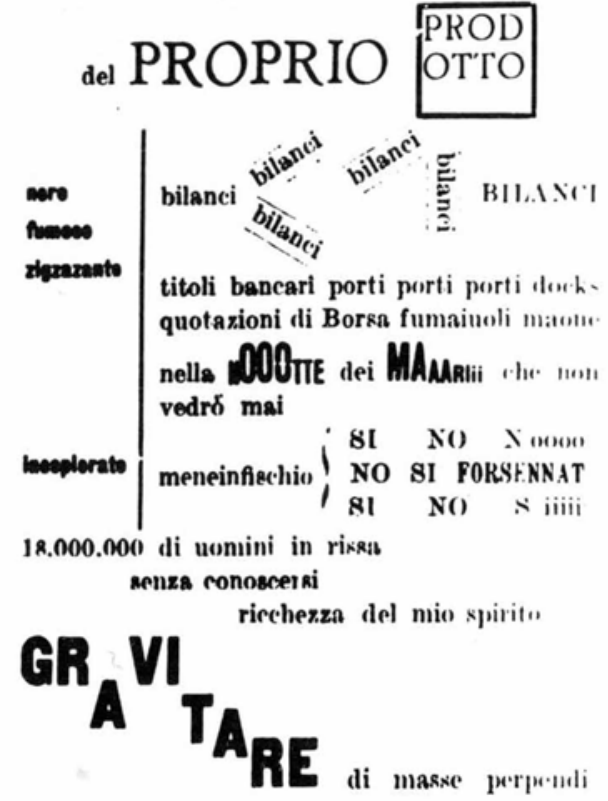
quotaxioni di Borea fumaiuoli matum.

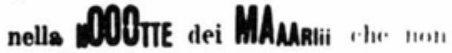
vedro mai

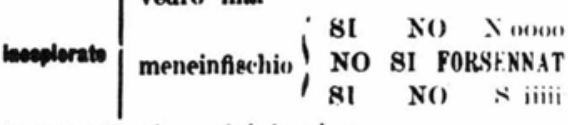

18.000.000 di uonini in rikeas

menza conoscei ki ricchesza del nio spirit"

\section{$\mathrm{GR}_{\mathbf{A}} \mathbf{V} \mathbf{T}_{\mathbf{A}_{\mathbf{R E}}}$}

di masxe perpu-uli

colari sul piano orizzontale dẹl mio 1 A LINO di niarmo

RIBITE R V B $\mathrm{L}_{\mathrm{L}} \mathrm{I}$ contro volonti SFTE CEREHRALE LUSSO

odori di 41 femmine (occaslonale cronamitrato rastrellante) $=8$ siluri $=$ LUS SILUA 4 slittare slittare slittare sul penkiero

\section{DOMINANTE delln \\ mis POVERTA}

FOR\%A COMMERCIALE della personalltì fistes di questi iapolavori d' $\mathbf{I}_{\operatorname{cov} A}^{\mathrm{A}}$ mercato notturno FIERA (meruviglioso glostrante flluminatissimo tintinnante)

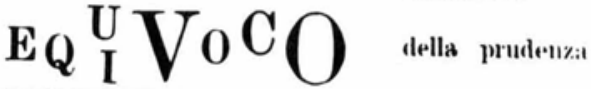
- jercuniurlé ácidentalità inebriante avvilimento visione (novtulgi('o) sprezanute in-

\section{Carlo Carrá, Parole in libertá (1914).}




\section{SINTESI FUTURISTA DELLA GUERRA}

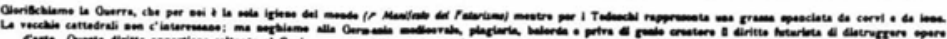

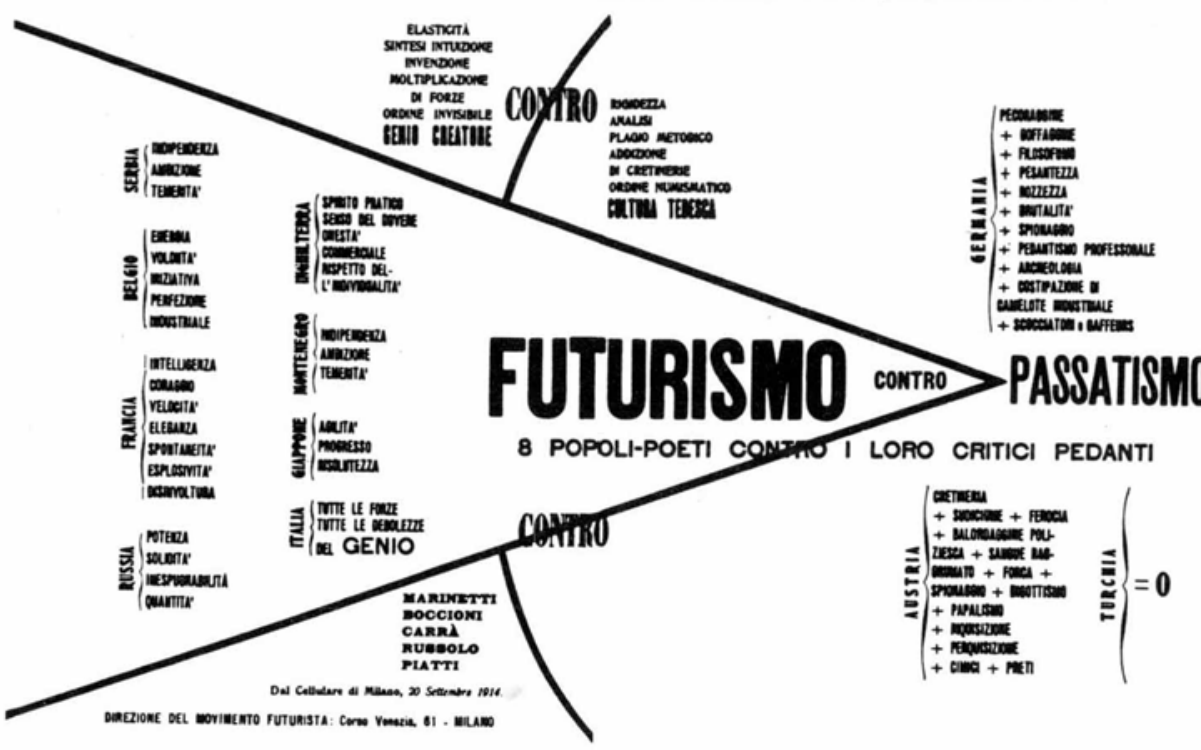

10. Carlo Carrá, Parole in libertá (1914). 

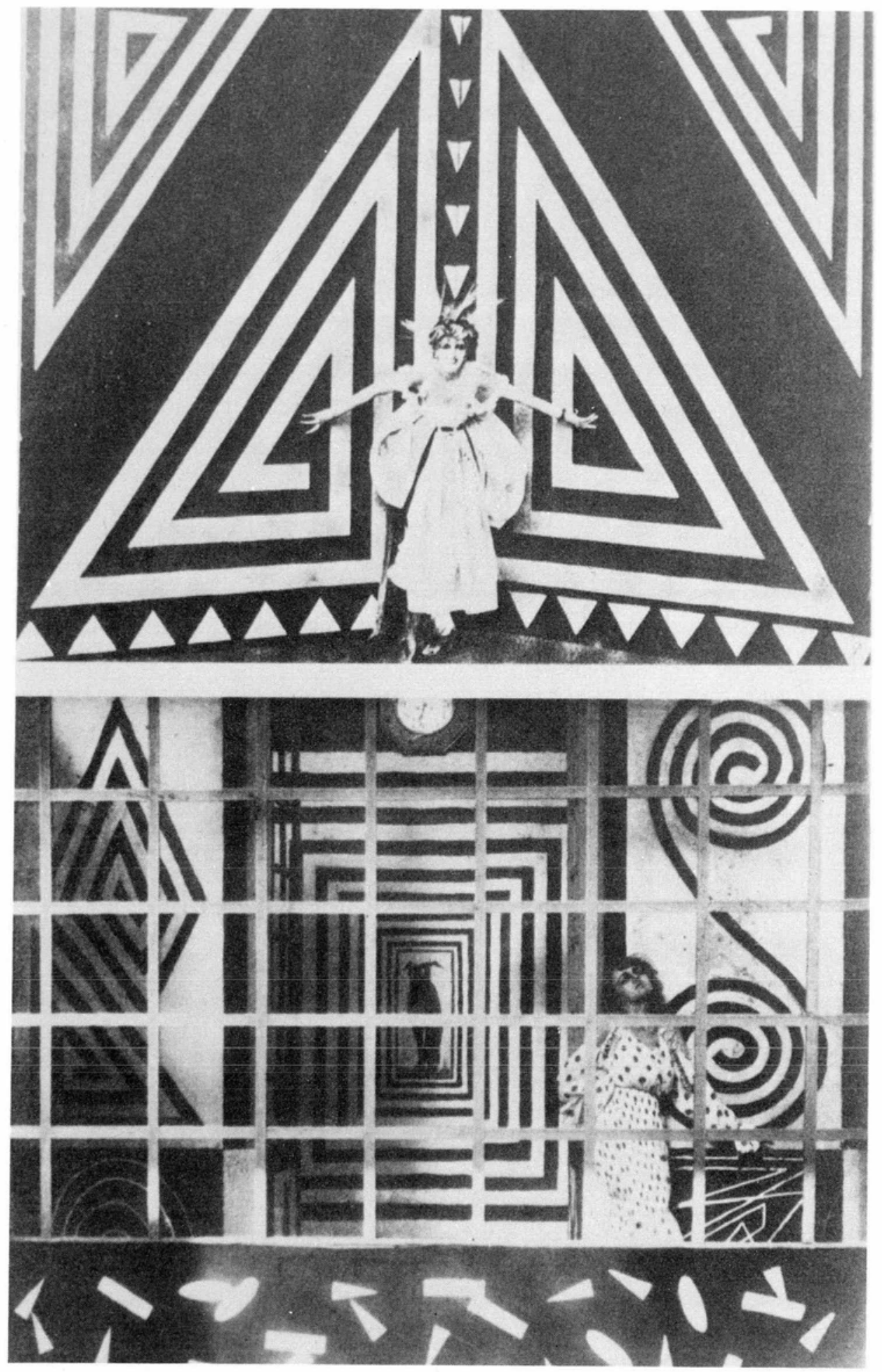

11. Anton Giulio Bragaglia, escenas de la película Thais, con la bailarina rusa Thais Galitzky (1916). 
DOI: http://dx.doi.org/10.22201/iie.18703062e.1993.64.1673

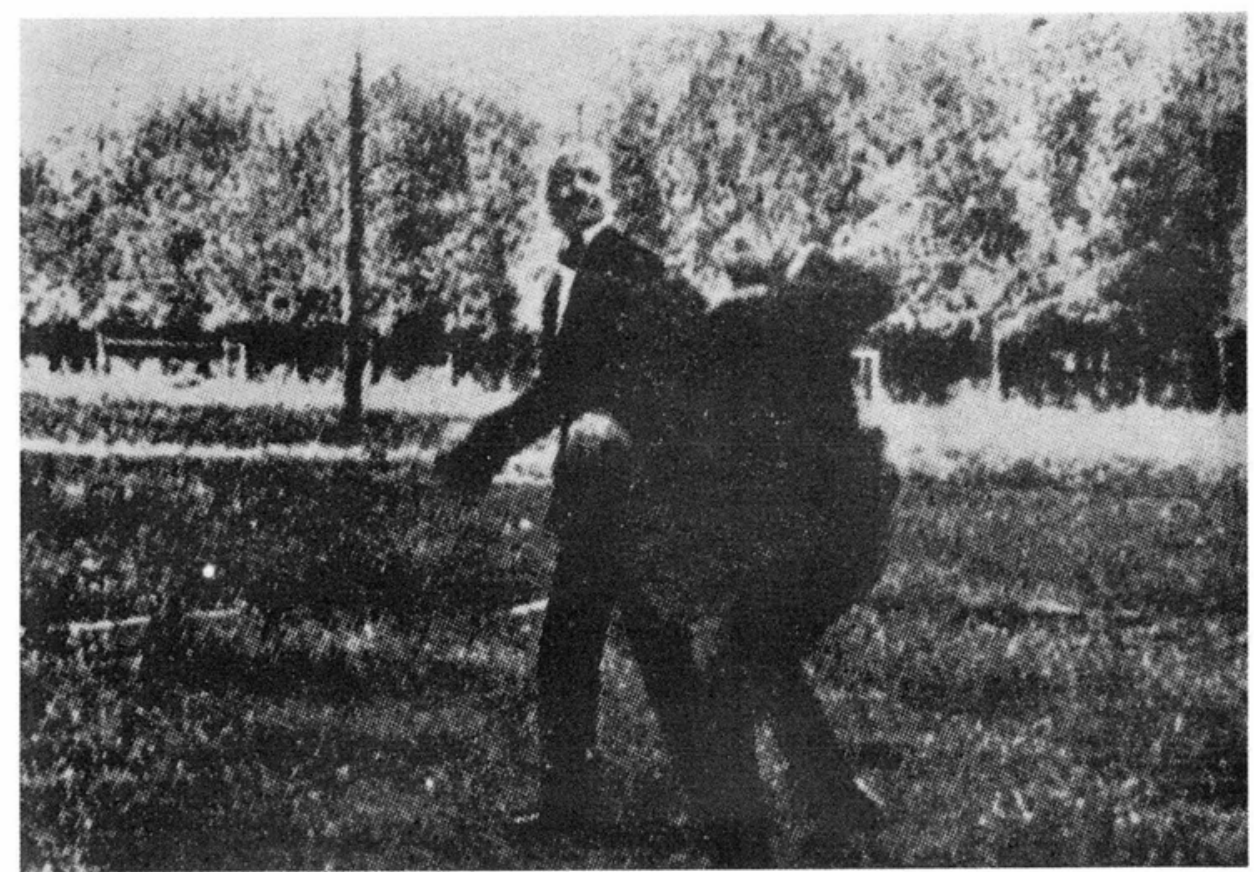

12. Escena del cortometraje futurista Cazzotatura futurista (1917) de Corra e Ginna. 
El fotodinamismo produjo reacciones encontradas en los futuristas. Balla y Russolo lo aceptaron; se sabe que cuando menos Boccioni y Severini lo rechazaron, con seguridad porque estaban sensibles a las críticas que les habían hecho en París, donde los calificaron de "fotográficos, antiartísticos y cinematográficos" ${ }^{45}$ Los futuristas pretendieron hablar en el manifiesto técnico a los parisinos con un lenguaje surgido en París, donde seguramente aún no se desvanecía la memoria sobre los inicios del invento de los hermanos Lumière. Tales críticas parecen ser el origen de negar sistemáticamente todo parentesco con Marey y con el cine; como Bragaglia hacía evidentes tales nexos, Boccioni recomendaba a Severini evitar

cualquier contacto con la fotodinámica de Bragaglia, una presuntuosa inutilidad que perjudica nuestras aspiraciones de liberarnos de la reproducción esquemática o sucesiva de lo estático y del movimiento.

\section{Califica al fotodinamismo de}

grafomanía de un fotógrafo positivista del dinamismo [...] su libelo me ha parecido [.... ] simplemente monstruoso.. Grotesca la prosopopeya y fatuo sobre lo inexistente $^{46}$

A pesar de las limitaciones de Bragaglia y a pesar de las objeciones de Boccioni, Balla trabajó durante un tiempo estrechamente con el fotodinamismo, al grado de pintar algunos cuadros a partir de fotografías tomadas por Bragaglia, como Le mani del violinista (1912), documentado en Le due note maestre (1912). Es posible también que Dinamismo di un cane al guinzaglio (1912) y Bambina che corre sul balcone (1912) las haya basado en fotografías de Bragaglia. A esta época corresponde la copia casi fotográfica de una cronofotografía de Marey ya mencionada.

\section{Marinetti y el cine}

El acercamiento de Marinetti al cine fue gradual. Un primer contacto se dio a través de las veladas futuristas en los teatros de varias ciudades, donde se familiarizó con la tipografía de los programas de mano repartidos en las calles y a la entrada de teatros y cines; luego a través de las discusiones con

\footnotetext{
${ }^{45}$ Carrieri, op. cit, p. 106.

${ }^{46}$ De Marchis, op cit., pp. $24-25$
} 
los pintores que se adhirieron al futurismo en el transcurso de 1910, donde debió conocer la obra de Marey; en particular debió recibir la influencia de Giacomo Balla. Por último, parece haberse abierto plenamente al cine a través de la influencia de Anton Giulio Bragaglia, a quien empezó a tratar en 1911.

Marinetti se había propuesto cambiar radicalmente los hábitos no sólo de la cultura, sino de Italia entera. De ahí su incansable organización de veladas. Como necesitaba un auditorio numeroso, prefería los teatros a las galerías porque la dimensión de éstas restringía la cantidad de público. Las llevó a cabo primero en las ciudades más importantes de Italia: Venecia, Trieste, Turín, Milán, Roma; luego en el extranjero: Londres, París, Moscú.

Marinetti en esta época estaba preocupado sobre todo por propagar su idea del verso libre para liberar a la poesía de los cánones que a su juicio la ataban y la rigidizaban. El 11 de mayo de 1912 publicó su manifiesto técnico de la literatura, donde planteó la posibilidad de las palabras en libertad. En la segunda edición del manifiesto, el 11 de mayo de 1913, menciona al cine:

[...] un tímido, sedentario habitante de cualquier pueblo provinciano puede dar rienda suelta a su intoxicación de peligro yendo al cine para mirar una gran cacería en el Congo. Puede admirar atletas japoneses, boxeadores negros, infatigables excéntricos norteamericanos lo mismo que a la más elegante mujer parisina $[\ldots]^{47}$

En septiembre de ese mismo año vuelve a referirse al cine en el manifiesto sobre el teatro de variedades, el cual utilizaba al cine para enriquecer el espectáculo con imágenes de batallas, de tumultos, de carreras de caballos, de encuentros de automóviles y aeroplanos, de viajes y viajeros, de los arrabales de la ciudad, del campo, de océanos, de la región de los hielos, proyectadas durante la función. ${ }^{48}$

Programarse en los teatros lo puso en contacto con los programas de teatro y de cine de varios países, pues desde el punto de vista tipográfico entre éstos y los manifiestos de las palabras en libertad existen numerosos vasos comunicantes.

En los estudios sobre los futuristas que he tenido a la mano, ninguno publica el facsímil de la primera y segunda ediciones del manifiesto técnico de la literatura, para estudiar su tipografía. Lo más temprano de Marinetti

\footnotetext{
${ }^{47}$ Apollonio, op cit., p. 76, texto del manifiesto Destrucción de la sintaxis-imaginación sin hilos-palabras en libertad.

${ }^{48}$ Idem, p. 115.
} 
relacionado con su revolución tipográfica que he podido detectar es el $M a$ nifiesto de la antitradición futurista, de junio de 1913, diseñado por él, según cuenta Carlo Carrà. ${ }^{49} \mathrm{El}$ diseño sigue de cerca el de los programas de cine en dos aspectos:

a) en el papel de color;

b) en la composición tipográfica.

Los programas de cine, herederos de la tradición teatral y circense, se caracterizaban por ser impresos en papel corriente de varios colores: blanco, amarillo, rosa, azul, igual que los colores empleados por Marinetti para el manifiesto de Apollinaire, así como por su juego tipográfico, estimulado por la exhibición de numerosas películas en una misma sesión, por ser las películas demasiado breves (las primeras de uno y medio a tres minutos de duración; en México hubo sesiones de 75 y 100 películas), lo que obligaba a los empresarios a listarlas y a expresar la importancia de la película en los valores tipográficos de los títulos de las mismas. Como las sesiones eran por tandas de cinco o diez películas, en cada bloque había que destacar las más importantes. Esto es un fenómeno universal desde las primeras exhibiciones cinematográficas (figura 8).

Visualmente, los programas son de una extraordinaria riqueza tipográfica, que desde luego llamó la atención de Marinetti para usarla como fuente de su revolución tipográfica.

Siguiendo la propuesta tipográfica de Marinetti en el manifiesto de Apollinaire, Carlo Carrà escribe textos de palabras en libertad con características tipográficas similares. Incluso transcribe el perfil del rayo luminoso que emana del proyector cinematográfico y establece un paralelo entre éste y la letra A acostada (figura 9), que repite amplificadamente en la Sintesi futurista della guerra (figura 10).

Por otra parte, algunos de los textos de las palabras en libertad de Carrà tienen símil con intertítulos de películas mudas unidos, esto es, sin secuencias de imágenes de por medio, porque las películas mudas se componían de secuencias de imágenes interrumpidas por intertítulos explicativos; éstos no tenían ninguna hilación entre sí porque se componían en función de la secuencia que se iba a explicar. Debían estar compuestos con frases breves, sintéticas, expresivas e independientes. Al unir los intertítulos, el texto difícilmente tenía sentido; carecía de significado porque aquéllos habían sido compuestos en función de las secuencias visuales

${ }^{49}$ Carrieri, op cit., p. 89 
que apoyaban. Juntándolos, satisfacían las propuestas de Marinetti de las palabras en libertad. Tomemos unos ejemplos del texto de Carrà: las frases "pace delle campagne primavera" y "ciuffi di neve Alpi Italia" parecen provenir de películas de geografia, comunes en la época, de las que Carrá eliminó preposiciones: "pace delle campagne in primavera" y "ciuffi di nevi degli Alpi d'Italia". De la misma composición, el siguiente bloque me parece que era un solo intertítulo:

\section{DOMINANTE \\ della \\ mia \\ povertà}

Desde luego que, al igual que las cronofotografías, no se trata de una transcripción literal de intertítulos, sino partir de ellos para las primeras composiciones de palabras en libertad. Después la tipografía seguiría su propia dinámica y olvidaría el modelo.

Unas palabras en libertad de Marinetti contienen las mismas características tipográficas del Manifiesto de la antitradición futurista de Apollinaire y las palabras en libertad de Carrà: al presentar el texto como listado de películas sobre fondo amarillo, de inmediato se asocia con los programas de cine, a pesar de iniciar su desprendimiento del modelo; además también encontramos frases al parecer provenientes de intertítulos de películas, en este caso de documentales italianos de propaganda con escenas de los campos de guerra de la Primera Guerra Mundial: "Sono capoposto in vedetta sul curvo sentiero a mezza costa", "Fuori delle trincee italiane a $100 \mathrm{~m}$. delle trincee austriache", "Eccellenti zappe picconi badilli presi agli austriaci", "lavoro febrile", "Se gli austriaci ci contrattacheranno li faremo ruzzolare giù dalla montagna", etcétera. No sé hasta qué punto las frases "Silenzio quasi totale" y "Buio totale+silenzio totale" se asocien a las funciones de cine; en particular a las indicaciones a los pianistas o a los músicos, contenidas en las partituras de la música compuesta especialmente para algunas películas que los distribuidores les hacían llegar.

Me parece no estar alejado de la realidad en esta asociación de la revolución tipográfica marinettiana con los programas de cine El problema para una afirmación categórica estriba en el afán de los futuristas de ocultar sus fuentes por su afán de originalidad. Esto mismo, como lo hemos visto, los llevó a negarlas. 


\section{Películas de vanguardia}

Bruno Corra [Bruno Giananni-Corradini] y Emilio Settimelli, simpatizantes de los futuristas, fundadores en 1912 del semanario El Centauro de Florencia, y autores en 1914 del manifiesto, avalado por Marinetti, Pesos, medidas y precios del genio artístico, publicaron en 1912 el artículo "Cine abstracto-música cromática", en el que informaban que en las películas Arco iris y $L a$ danza, de alrededor de 200 metros cada una, habían experimentado su búsqueda de masas de colores sin ninguna imagen figurativa, para crear una sinfonía cromática. Se trata, quizá, de las primeras películas de vanguardia, de las primeras películas abstractas, que anteceden incluso a las de los propios futuristas.

Dirigimos nuestros pensamientos al cine, y nos pareció que este medio, ligeramente modificado, podría dar excelentes resultados, desde que su potencia luminosa era mucho más fuerte que lo que uno podía desear [...] Con un simple instrumento cinematográfico, con una máquina de pequeñas dimensiones, podíamos obtener los innumerables efectos extremadamente poderosos de una gran orquesta, la verdadera sinfonía cromática [....]

Describieron pormenorizadamente la manera en que, después de varios fracasos y después de eliminar la emulsión que fija las imágenes, imprimieron sobre la película manchas de colores, tratando de dar un sentido cromático, hasta encontrar lo que buscaban:

En la primera película el tema son los colores del arcoiris, los cuales surgen ocasionalmente en diferentes formas y con intensidad siempre creciente hasta una explosión final con una violencia deslumbradora. En La danza los colores predominan: el carmín, el violeta y el amarillo, que se unen, se separan y se lanzan hacia arriba continuamente como en la ágil pirueta de un trompo. ${ }^{50}$

El contacto de Marinetti con Corra y con Bragaglia fue definitivo; juntos firmaron el Manifiesto de la cinematografía futurista, del 11 de septiembre de 1916, avalado por Giacomo Balla y otros más, en el que proponían hacer del cine un sustituto de las revistas, del teatro y del libro. En el cine deseaban expresar los grandes bloques de palabras en libertad y los anuncios luminosos movibles. Después de revolucionar el teatro dramático y el teatro de variedades, sobre los cuales habían publicado sendos manifiestos y habían promovido una práctica a lo largo de toda Italia, consideraban necesario transportar su esfuerzo a otra zona del "teatro": al cinematógrafo.

${ }^{50}$ Apollonio, op cit., p. 70 
Ver al cine como parte del teatro nos habla de su incapacidad para apreciar la narrativa cinematográfica que para 1916 se había desarrollado notablemente, sobre todo en Italia con el filme histórico. En 1913 Giovanni Pastrone había filmado Cabiria, vanguardia de la narrativa y punto de partida de David Wark Griffith para El nacimiento de una nación (1914) e Intolerancia (1915), que marcaron la madurez expresiva del cine.

Quizá en 1916, a causa de la guerra, la obra de Griffith no se conociera en Italia; quizá el mismo cine italiano había caído en la rutina de los filmes de las divas, que no aportan nuevos elementos narrativos y sí cansancio, repetición y agotamiento temático. Quizá por lo anterior no apreciaban al cine como un arte con su propia especificidad, sino como un derivado del teatro, de ahí que se propusieran convertirlo en un arte para equipararlo con las demás artes visuales.

También vale la pena destacar que ahora no se trata de los principios que animaron a los hermanos Lumiére a crear el cinematógrafo, sino al aspecto narrativo; no se trata ya de fijar los objetos en movimiento, sino de aportar elementos creativos para hacer del cine un arte, con características peculiares.

A simple vista, el cinematógrafo, nacido hace pocos años, puede parecer ya futurista, esto es, privado de pasado y libre de ataduras: en realidad es como un teatro sin palabras, heredero de toda la basura del teatro literario. Por lo tanto, todo lo que hemos dicho para el teatro en prosa lo hacemos extensivo al cinematógrafo.

A su juicio, hasta ese día el cine

ha sido y tiende a permanecer profudamente sumido en el pasado, mientras que nosotros vemos en él la posibilidad de un arte eminentemente futurista y $e l$ medio de expresión más adaptado a la plurisensibilidad de un artista futurista. Las posibilidades artísticas del cine han permanecido absolutamente intactas.

El cinematógrafo es un arte por sí mismo. No debe, entonces, copiar más al teatro. El cinematógrafo, siendo esencialmente visual, debe ser la culminación de la evolución de la pintura; debe separarse de la realidad, de la fotografía, de lo gracioso y de lo solemne. Debe ser antigracioso, deformador, impresionista, sintético, dinámico, "parlolibero".

Debemos liberar al cinematógrafo como medio de expresión para hacerlo un instrumento ideal de un nuevo arte inmensamente más vasto y más ágil que todos los existentes. Estamos convencidos que sólo así podrá alcanzar la poliexpresividad 
hacia la cual tiende la más moderna investigación artística. El cinematógrafo futurista crea precisamente hoy la sinfonia poliexpresiva que anunciábamos hace un año en nuestro manifiesto Pesos, medidas y precios del genio artistico,

en el que abrían el concepto de arte al establecer que cada artista tenía la posibilidad de inventar un arte nuevo, para expresar con libertad las ideosincracias particulares de la constitución cerebral de cada quien, por loca y complicada que fuese, mezclado con una nueva medida y una nueva modalidad; con los medios de expresión más diversos: palabras, colores, notas, indicaciones de forma, de perfumes, de hechos, de rumores, de movimientos, de sensaciones físicas. En suma, lo que llamaban sinfonía poliexpresiva: "mezcolanza cromática, antiestética y exagerada de todas las artes ya existentes y de todas aquellas que son o serán creadas de la incontenible voluntad de renovación que el futurismo sabrá infundir en la humanidad" 51

De la misma manera en el filme futurista debían entrar los medios de expresión más variados,

de la línea a las palabras en libertad, de la música cromática y plástica a la música de objetos. Sería pintura, arquitectura, escultura, palabras en libertad, música de colores, líneas y formas, acoso de objetos y realidad caotizada [....

[....] ofreceremos nuevas inspiraciones a las búsquedas de los pintores los cuales tienden a forzar el límite del cuadro. Pondremos en movimiento las palabras en libertad que rompen el limite de la literatura enfilándose a la pintura, al arte de los rumores, tendiendo un maravilloso puente entre la palabra y el objeto real.

Agregaban que las películas futuristas serían analogías cinematográficas que usarían la realidad como punto de partida para expresar estados subjetivos del artista, con lo cual harían fantasías cinematográficas; de ahí que dijeran que el universo seria su vocabulario. Sus películas serían poemas, discursos y poesías aprovechando los intertítulos para actualizar la vieja poesía, transformándola radicalmente. Serían simultaneidad y compenetración de tiempos y lugares; serían una búsqueda musical con disonancias, sinfonías de gestos, de acordes, colores, líneas, hechos; estados de ánimo; dramas de objetos animados, humanizados, trucados, vestidos, apasionados, civilizados, danzantes; vitrinas de ideas, de tipos, de objetos; congresos, flirts, risas y matrimonios de muecas, de mímicas;

\footnotetext{
${ }^{51}$ Drudi Gamballo, op cit., pp. 43 y ss
} 
reconstrucción irreal del cuerpo humano; dramas de desproporciones cinematográficas; dramas potenciales y planos estratégicos de sentimientos; equivalencias lineales plásticas, cromáticas; palabras en libertad en movimiento cinematográfico

(bloques sinópticos de valores líricos-dramas de letras humanizadas o animalizadasdramas ortográficos-dramas tipográficos-dramas geométricos-sensibilidad numérica, etcétera.)

Pintura+escultura+dinamismo plástico+palabras en libertad+ "intonarumori"+ arquitectura+teatro sintético $=$ Cinematografía futurista

Descomponiendo y componiendo así el universo según nuestros maravillosos caprichos, para centuplicar la potencia del genio creador italiano y su predominio absoluto en el mundo ${ }^{52}$

Se trataba, en el fondo, de una reacción nacionalista, quizá estimulada por la obra de Griffith, que superó técnicamente a los italianos.

Ese mismo año de 1916 Anton Giulio Bragaglia filmó Pérfido encanto de 1389 metros, Thais (1446 metros)(figura 11) e Il mio cadavere (1380 metros), ${ }^{53}$ que precedieron al lanzamiento del manifiesto de la cinematografía. Después se filmó un cortometraje en Florencia, en diciembre de 1916 y enero de 1917, dirigido por Bruno Corra y Arnaldo Ginna, en el que actuaron Marinetti, Balla, Settimelli, Chiti y gente de la calle.

Pérfido encanto la produjo Emilio de Medio, rico intelectual romano, que proporcionó a Bragaglia el capital para fundar la compañía cinematográfica Novissima Film. Bragaglia informó que Ricardo Cassano lo ayudó en la dirección y en el guión; Enrico Prampolini en la escenografía; fotografió Giorgino Ricci; actuaron la bailarina clásica rusa Ileana Leonidov, Thais Galitzesky y Mario Coronetuto, actores no profesionales. "El argumento es una historia de amor resuelta en episodios realistas y surrealistas." Se explotó co-mercialmente; suscitó escándalo e hilaridad del público. Una copia se conserva, al parecer en mal estado, en el Museo del Cine de París.

El cortometraje florentino, a juicio de las fotografías que se conocen, fue un "puñetazo futurista" ${ }^{54}$ (figura 12).

No se sabe de más experimentos fílmicos. Quizá entre los varios problemas que enfrentaron, y que no habían tenido en sus experiencias artísticas

59 Idem, pp. 96-99

53 Tisdall, op. cit, pp. 243 y ss.

${ }^{54}$ Drudi Gamballo, op cit., pp. 493-500. 
previas, estaba la condición industrial del cine, que lo hacía un arte caro y lo convertía en espectáculo necesariamente masivo para recuperar el costo de la inversión, y de compleja técnica cuyo dominio implicaba un ejercicio constante; lo más probable es que, al igual que Pérfido encanto, y el resto de los cortometrajes, significara un tropiezo.

Los experimentos filmicos de los futuristas, aunque tuvieron el propósito de llegar a un público amplio, no trascendieron el ensayo de probeta, por lo cual se quedaron dentro del mismo círculo de seguidores. $A$ pesar de ser una búsqueda formal cinematográfica propiamente dicha, esto es, hacer un filme, no tomar una vista de un objeto en movimiento, las experiencias cinematográficas de los futuristas no tuvieron continuidad.

Pero en Rusia, donde el futurismo había llegado muy pronto y pronto se extendió, se adoptó y tomó características propias; donde en 1914, antes del manifiesto de la cinematografía futurista de los italianos, se filmó Drama en un café futurista, tragicomedia de dos rollos dirigida por V.P. Kasinov, las condiciones creadas por la revolución de octubre permitirían experimentar propuestas futuristas italianas, lo cual será tema del próximo artículo ${ }^{55}$

${ }^{55}$ Guido Aristarco, Historia de las teorias cinematográficas, Barcelona, Lumen, 1968, pp. $131-$ 